Repository of the Max Delbrück Center for Molecular Medicine (MDC) Berlin (Germany)

\title{
Phase 1 Trial of Allogeneic Gene-Modified Tumor Cell Vaccine RCC-26/CD80/IL-2 in Patients with Metastatic Renal Cell Carcinoma
}

Heike Pohla, Gerald Willimsky, Bernhard Frankenberger, Ronald Frank, Andrea Baur-Melnyk, Michael Siebels, Christian G. Stief, Alfons Hofstetter, Joachim Kopp, Antonio Pezzutto, Thomas Blankenstein, Ralph Oberneder, and Dolores J. Schendel

This is a copy of an article published in the "Human Gene Therapy" (C) 2010 copyright Mary Ann Liebert, Inc.; "Human Gene Therapy" is available online at: http://online.liebertpub.com. 


\title{
Phase 1 Trial of Allogeneic Gene-Modified Tumor Cell Vaccine RCC-26/CD80/IL-2 in Patients with Metastatic Renal Cell Carcinoma
}

\author{
Alexander Buchner, ${ }^{1,2 *}$ Heike Pohla, ${ }^{2,3 *}$ Gerald Willimsky, ${ }^{4,5 *}$ Bernhard Frankenberger, ${ }^{3}$ Ronald Frank, ${ }^{6}$ \\ Andrea Baur-Melnyk, Michael Siebels, Christian G. Stief, Alfons Hofstetter, Joachim Kopp, ${ }^{2}$ \\ Antonio Pezzutto, ${ }^{8,9}$ Thomas Blankenstein, ${ }^{4,5 *}$ Ralph Oberneder, ${ }^{1,10 *}$ and Dolores J. Schendel ${ }^{3 \star}$
}

\begin{abstract}
Preclinical studies showed that the allogeneic tumor cell line RCC-26 displayed natural immunogenic potential that was enhanced through expression of CD80 costimulatory molecules and secretion of interleukin-2. Here we report the study of RCC-26/CD80/IL-2 cells in a phase 1 vaccine trial of renal cell carcinoma patients with metastatic disease (mRCC). Fifteen patients of the HLA-A*0201 allotype, with at least one metastatic lesion, were included. Irradiated vaccine cells were applied in increasing doses of $2.5,10$, and $40 \times 10^{6}$ cells over 22 weeks. Primary study parameters included safety and toxicity. Sequential blood samples were analyzed by interferon- $\gamma$ enzyme-linked immunospot assays to detect tumor antigen-associated (TAA) effector cells. The vaccine was well tolerated and the designated vaccination course was completed in 9 of 15 patients. Neither vaccine-induced autoimmunity nor systemic side effects were observed. Delayed-type hypersensitivity skin reactions were detected in 11 of 12 evaluated patients and were particularly strong in patients with prolonged survival. In parallel, vaccine-induced immune responses against vaccine or overexpressed TAA were detected in 9 of 12 evaluated patients. No tumor regressions occurred according to RECIST (Response Evaluation Criteria in Solid Tumors) criteria; however, median time to progression was 5.3 months and median survival was 15.6 months, indicating substantial disease stabilization. We conclude that vaccine use was safe and feasible in mRCC. Clinical benefits were limited in these patients with advanced disease; however, immune monitoring revealed vaccine-induced responses against multiple TAAs in the majority of study participants. These results suggest that this vaccine could be useful in combination therapies and/or minimal residual disease.
\end{abstract}

\section{Introduction}

$\mathbf{U}$ P то 30\% OF PATIENTS with renal cell carcinoma (RCC) have metastatic disease at the time of diagnosis, and metastases develop metachronously in $20-40 \%$ of patients undergoing partial or radical nephrectomy for clinically localized tumors (Janzen et al., 2003). Targeted molecular therapies have become available that can slow tumor progression, offering new hope for patients with metastatic RCC (mRCC). These therapies are directed primarily toward interruption of signaling pathways that foster angiogenesis (Longo et al., 2007). Although initial retardation of tumor growth is achieved with several new classes of angiogenesis inhibitors and some tumors show regression in imaging, most

\footnotetext{
${ }^{1}$ Department of Urology, Ludwig Maximilian University of Munich, 81377 Munich, Germany.

${ }^{2}$ Laboratory of Tumor Immunology, LIFE Center, Ludwig Maximilian University of Munich, 81377 Munich, Germany.

${ }^{3}$ Institute of Molecular Immunology, Helmholtz Zentrum München, German Research Center for Environmental Health, and Clinical Cooperation Group "Immune Monitoring," 81377 Munich, Germany.

${ }^{4}$ Max Delbrück Center for Molecular Medicine, 13092 Berlin, Germany.

${ }^{5}$ Institute of Immunology, Charité-University Medicine, Campus Benjamin Franklin, 12200 Berlin, Germany.

${ }^{6}$ Department of Chemical Biology, Helmholtz Center for Infection Research, 38124 Braunschweig, Germany.

${ }^{7}$ Department of Clinical Radiology, Ludwig Maximilian University of Munich, 81377 Munich, Germany.

${ }^{8}$ Department of Hematology, Oncology, and Tumor Immunology, Charité-University Medicine, Campus Berlin-Buch, 13125 Berlin, Germany.

${ }^{9}$ Department of Hematology and Oncology, Charité-University Medicine, Campus Virchow-Klinikum, 13353 Berlin, Germany.

${ }^{10}$ Present address: Urological Clinic Dr. Castringius Munich-Planegg, 82152 Munich-Planegg, Germany.

*A.B., H.P., G.W., T.B., R.O., and D.J.S. contributed equally to this study.
} 
patients with RCC develop therapy resistance over time (Sosman et al., 2007). Therefore, there is still an important therapeutic need for patients with metastatic disease.

Among patients with cancer, those with RCC show some of the most favorable responses to immunotherapy (Kim et al., 2003; Motzer, 2003). Cancer vaccines represent one treatment strategy to exploit this immunological potential because there is evidence that immunization against tumors can reduce or even eliminate some tumors and induce longlasting $\mathrm{T}$ cell memory responses with a capacity to control tumor relapse. Nevertheless, vaccine treatment alone has shown clinical benefit in only a small number of patients with mRCC (Simons et al., 1997; Frankenberger et al., 2005b; Schendel, 2007). Thus, future treatment strategies that combine targeted molecular therapies with low-toxicity vaccination might enhance the development of effective immune responses and improve the long-term perspectives of patients with advanced disease.

Various vaccine strategies have been developed to induce antitumor T cell responses (Pardoll, 1998), several of which have been applied in patients with mRCC (Frankenberger et al., 2005b; Schendel, 2007). One approach is to use autologous gene-modified tumor cells as vaccines, introducing immunologically relevant genes to enhance tumor cell immunogenicity (Mach and Dranoff, 2000). The first phase 1 trial in RCC implementing this strategy, through introduction of the gene encoding granulocyte-macrophage colonystimulating factor (GM-CSF) into autologous tumor cells, demonstrated clinical benefit in several patients (Simons et al., 1997) and induction of specific T cell immunity (X. Zhou et al., 2005). More recently, an autologous gene-modified tumor cell vaccine that expressed the costimulatory molecule CD80 was tested in patients with mRCC in combination with systemic interleukin (IL)-2 (Antonia et al., 2002; Fishman et al., 2008). No severe toxicity was associated with these vaccines. However, strong limitations in feasibility and high costs are incurred with the production of individualized genemodified tumor cell vaccines. Generic vaccines that could be applied to many patients would reduce development time and costs and enable treatment of more patients.

We developed an allogeneic gene-modified RCC vaccine based on a well-characterized tumor cell line that showed improved immunogenicity through expression of CD80 and IL-2 (Frankenberger et al., 2005a). The original cell line (RCC26) (Schendel et al., 1993) was derived from an HLA-A*0201positive patient with stage I disease (pT1pN0M0G2) in whom only a single brain metastasis appeared after nephrectomy, following a disease-free interval of 9 years. The RCC$26 / C D 80 /$ IL-2 vaccine was tested in a clinical phase 1 trial to evaluate safety and feasibility with stage IV mRCC patients matched for the HLA-A*0201 allotype. Furthermore, the ability of vaccination to induce specific $\mathrm{T}$ cell reactivity was analyzed with enzyme-linked immunospot (ELISPOT) assays to detect $\mathrm{T}$ cell responses to vaccine cell lysates as well as to surrogate peptides that were derived from tumor-associated antigens (TAAs) that are overexpressed in mRCC lesions.

\section{Materials and Methods}

\section{Patients}

Between September 2003 and August 2006, 15 patients with histologically proven clear-cell RCC and at least one evaluable metastasis were enrolled in the clinical study. This study is registered with the German Somatic Gene Transfer Clinical Trial Database (DeReG [Deutsches Register für somatische Gentransferstudien], reference number 47). Potential study patients were screened for the HLA-A*0201 allotype first by serological typing using flow cytometry, followed by genotyping with an HLA-A*02-specific polymerase chain reaction (PCR), as described previously (Gatz et al., 2000). The PCR product encompassing exons 2 and 3 was subsequently sequenced. Only patients with an HLA$A^{*} 0201$ subtype were finally included in the clinical study. Further inclusion criteria were good performance status (Eastern Cooperative Oncology Group [ECOG] score, 0 or 1), no surgery during the previous 4 weeks, no systemic antitumoral therapy during the previous 12 weeks, no evidence of autoimmune disease, and no use of systemic immunemodulatory therapies (e.g., corticosteroids). Initial staging on the basis of computer tomography (CT) and bone scan was performed 1 week before the first vaccination. All patients gave written informed consent before entering the study. The trial protocol was approved by the local ethics committee and the good manufacturing practice (GMP)-certified vaccine production was approved by the responsible national, state, and local authorities.

\section{Vaccination and study schedule}

The genetically modified RCC-26/CD80/IL-2 vaccine was generated as described previously (Frankenberger et al., 2005a). The cells were expanded under GMP conditions and stored in the gas phase of liquid nitrogen in ampoules with $2.5 \times 10^{6}$ or $10 \times 10^{6}$ cells. For safety reasons, all cryopreserved vaccine aliquots were irradiated $(120 \mathrm{~Gy})$ in one batch under controlled conditions. The vaccine cells were thawed immediately before patient application and given by intradermal injection into the inguinal region. Graded doses of cells were applied up to 10 times over a 22-week period. The vaccination schedule was as follows: $2.5 \times 10^{6}$ cells at weeks $1,2,4$, and 6; $10 \times 10^{6}$ cells at weeks $8,10,12$, and 14 ; and $40 \times 10^{6}$ cells at weeks 18 and 22. Clinical examination and routine blood checks were performed at every visit. Patients were assessed for signs of autoimmune disease by measurement of thyroid hormones and pancreatic enzymes, screening for anti-nuclear antibodies, as well as monitoring of rheumatoid factor and complement factors. Blood samples for immune monitoring were taken at weeks $1,6,14,22$, and 36. Restaging on the basis of CT was performed at weeks 8, 18, 24, and 36. Patients were withdrawn from the study on evidence of tumor progression according to the Response Evaluation Criteria in Solid Tumors (RECIST) (Therasse et al., 2000). In four patients, the lowest vaccine dose $\left(2.5 \times 10^{6}\right.$ cells $)$ was omitted and vaccination was initiated with a dose of $10 \times 10^{6}$ cells.

\section{Delayed-type hypersensitivity testing}

We assessed the patients for delayed-type hypersensitivity (DTH) reactions to challenge with irradiated vaccine cells after 4,8 , and 10 vaccinations at weeks 6,14 , and 22, respectively. Skin tests were performed by intradermal injection of $2.5 \times 10^{6}$ cells at a site distant from the vaccination sites in the inguinal region. A DTH reaction evaluated $48 \mathrm{hr}$ postchallenge was judged as positive if induration or erythema of at least $10 \mathrm{~mm}$ was observed. 


\section{Microarray analysis of TAA expression in tumors and $\mathrm{RCC}-26$ cells}

Tissue samples from 32 patients with clear-cell RCC metastases were collected, snap-frozen, and stored in liquid nitrogen after written informed consent had been obtained. Cryostat sections were made and laser microdissection was used to isolate tumor cells (PALM MicroBeam; Zeiss, Munich, Germany). Total RNA was extracted from these cells and also from RCC-26 cells (RNeasy micro kit; Qiagen, Hilden, Germany). RNA integrity was tested by capillary electrophoresis (2100 Bioanalyzer; Agilent, Santa Clara, CA). Thereafter, RNA amplification and hybridization on oligonucleotide microarrays (GeneChip Human Genome U133 Plus 2.0 array; Affymetrix, Santa Clara, CA) were performed with the manufacturer's reagents in accordance with the standard protocol. Normalized expression values were calculated for every transcript, using dChip software (Li and Wong, 2001) (A. Buchner, unpublished data). Expression levels of survivin, cyclin D1, adipophilin, and c-Met were quantified by quantitative real-time polymerase chain reaction (qRT-PCR) according to methods described elsewhere (Frankenberger et al., 2005a). Primer sequences are available on request.

\section{Immune monitoring}

Blood samples from the patients were drawn at study weeks 1, 6, 14, 22, and 36, and peripheral blood mononuclear cells (PBMCs) were isolated by density gradient centrifugation using Leucosep (Greiner Bio-One, Frickenhausen, Germany) and cryopreserved. Additional samples from five patients were taken on day 15 after the last (tenth) vaccination and samples were available from two patients during longer follow-up. For interferon (IFN)- $\gamma$ ELISPOT assays, the cells were thawed, washed with CTL Wash supplement medium (Cellular Technology, Cleveland, $\mathrm{OH}$ ) plus Benzonase nuclease (Novagen Merck Biosciences, Darmstadt, Germany), rested, and seeded at $1.5 \times 10^{5}$ cells in quadruplicate on antibody-precoated polyvinylidene difluoride (PVDF) plates (Mabtech, Nacka, Sweden). The PBMCs were stimulated directly with selected peptides (each peptide, $5 \mu \mathrm{g} / \mathrm{ml}$ ) in serum-free culture medium (CTL Test medium; Cellular Technology), supplemented with CD28 $(1 \mu \mathrm{g} / \mathrm{ml}$; BD Biosciences, San Jose, CA) and recombinant IL-2 (Proleukin, $2 \mathrm{U} / \mathrm{ml}$; Chiron, Emeryville, CA). The assays were developed as previously described (Brill et al., 2007). Spots were counted with AID reader system ELR03 with software version 4.0 (Autoimmun Diagnostika [AID], Strassberg, Germany) and controlled by human audit. The performance of the assay was externally validated by participation in the immune assay proficiency panels of the international Cancer Vaccine Consortium at the Cancer Research Institute, New York, USA (Janetzki et al., 2008) and the Association for Immunotherapy of Cancer (CIMT), Mainz, Germany (Britten et al., 2008). Definition of positive responses was based on proposed international criteria (Britten et al., 2008; Janetzki et al., 2008).

Surrogate peptides for immune monitoring were selected from sequences of TAAs shown to be overexpressed in metastatic RCC lesions and/or the vaccine cells, using HLAA*0201 motif-based epitope predictions available on the web (http://www.syfpeithi.de), or as published in the literature. Peptides specific for the following antigens were used: survivin
(ELTLGEFLKL ${ }_{95-104}$, TLPPAWQPFL $_{5-14}$ [Schmitz et al., 2000]), heteroclitic survivin-related peptide (LMLGEFLKL $69-104$ [Otto et al., 2005], EKVRRAIEQL $129-138)$, cyclin D1 (LLGATCMFV $_{101-109,}$ RLTRFLSRV $228-236$ [Sadovnikova et al., 1998]), adipophilin (SVASTITGV $129-137$, TLLSNIQGV $_{327-335}$ [Weinschenk et al., 2002], VMAGDIYSV $348-356)$, c-Met protooncogene (YVDPVITSI ${ }_{654-662}$, VLAPGILVL 6 -14, GLIAGVV$\mathrm{SI}_{31-39}$ [Weinschenk et al., 2002]), regulator of $\mathrm{G}$ protein signaling (RGS-5) (LAALPHSCL $5-13$ [Kruger et al., 2005], ILLQKPDSV $_{25-33}, \quad$ KLLQNNYGL $\left._{67-75}\right)$, apolipoprotein L (ALADGVQKV $176-184$ [Weinschenk et al., 2002], FLGENISNFL $_{242-251}$ [Flad et al., 1998]), mucin (MUC)-1 (STAPPVHNV $_{130-138}$, LLLLTVLTV $_{12-20}$ [Apostolopoulos et al., 1997; Brossart et al., 1999]), KIAA0367 (PRUNE2) (ALFDGDPHL $1-9$ [Weinschenk et al., 2002]), oncofetal antigen (OFA) (LLLAAR$\mathrm{AIV}_{60-68}$, LAARAIVAI $_{58-66}$ [Siegel et al., 2003]), human telomerase reverse transcriptase (hTERT) (ILAKFLHWL $540-548$ [Vonderheide et al., 1999], RLVDDFLLV ${ }_{865-873}$ [Minev et al., 2000]), vascular endothelial growth factor (VEGF) (LLSWVHWSL $_{4-12}$, ALLLYLHHA $13-21$ ), NY-ESO-1 (SLLMWITQC $157-165$, SLLMWITQCFL $_{157-167}$ [Jager et al., 1998]), Her2/neu (ALCRWGLLL $_{5-13}$ [Kawashima et al., 1998], HLYQGCQVV ${ }_{48-56}$ [Scardino et al., 2001]), melanoma-associated antigen (MAGE)A1 (KVLEYVIKV ${ }_{278-286}$ [Pascolo et al., 2001]), MAGE-A3 (FLWGPRALV 271-279 [van der Bruggen et al., 1994; M. Zhou et al., 2005], KVAELVHFL $112-120$ [Kawashima et al., 1998]), MAGE-A6 (ALSRKVAKL $108-116$ ), MAGE-A3/A6 (TLVEVTL$\mathrm{GEV}_{44-53}$ ), and Wilms' tumor suppressor antigen (WT-1) (RMFPNAPYL $126-134$ [Oka et al., 2000]).

Peptide synthesis and vaccine cell lysate preparation were performed as described previously (Brill et al., 2007). An irrelevant peptide for $\mathrm{Bcr} 3 / \mathrm{Abl} 2$ [SSKALQRPV ${ }_{926-934}$ (Yotnda et al., 1998)] was used as a negative control and the HLA-A2 CEF (human cytomegalovirus, Epstein-Barr virus, and influenza virus) peptide pool (CMVpp65, NLVPMVATV $495-503$; EBV-BMLF1, GLCTLVAML 280-288; EBV-LMP-2, CLGGLLT$\mathrm{MV}_{426-434}$; influenza M1 protein, GILGFVFTL ${ }_{58-66}$; and influenza RNA polymerase PA, FMYSDFHFI ${ }_{46-54}$ ), with $0.2 \mu \mathrm{g}$ of each peptide per well, was used as a positive control (PANATecs, Tübingen, Germany).

\section{Statistics}

Time to progression and tumor-specific survival were analyzed by the Kaplan-Meier method.

\section{Results}

\section{Characteristics of study patients}

Table 1 summarizes the characteristics of the patients enrolled in this study. There were more male than female participants (11 males vs. 4 females) and the patients ranged in age from 39 to 78 years (mean, 59 years) at study entry. In nine patients, the time from first diagnosis to disease progression and study entry was 2 years or less. This interval was 3-12 years for six patients, with three patients showing disease progression only after 8,11 , and 12 years. The TNMG classification of the tumors was variable. At the time of enrollment, the majority of patients had multiple metastases at two or more sites, revealing their advanced states of disease. All but two patients had lung lesions and the second most prevalent site of metastasis was the lymph node. According to the study protocol, all patients had good performance 
Table 1. Patient Characteristics

\begin{tabular}{|c|c|c|c|c|c|c|c|}
\hline$I D$ & Gender & $\begin{array}{c}\text { Age (years) } \\
\text { at first } \\
\text { diagnosis }\end{array}$ & $\begin{array}{c}\text { Age (years) } \\
\text { at study } \\
\text { entry }\end{array}$ & TNMG & $\begin{array}{c}\text { Prognostic } \\
\text { score }^{\mathrm{a}}\end{array}$ & $\begin{array}{c}\text { Therapy before } \\
\text { study entry }\end{array}$ & $\begin{array}{l}\text { Site(s) of } \\
\text { metastases }\end{array}$ \\
\hline MR-1 & $\mathrm{M}$ & 39 & 40 & pT2pN0M0G2 & 2 & - & Lung, bone \\
\hline MR-2 & $\mathrm{M}$ & 65 & 67 & pT2pN0M1G3 & 1 & Cytokine, $^{\mathrm{b}} \mathrm{G} 250^{\mathrm{c}}$ & Lung, LN \\
\hline MR-3 & $\mathrm{M}$ & 77 & 78 & pT3aNxM1G2 & 2 & - & Lung \\
\hline MR-4 & $\mathrm{F}$ & 66 & 68 & pT3bpN0M1G2 & 1 & Cytokine, G250 & Lung, LN, adrenal gland \\
\hline MR-5 & $\mathrm{M}$ & 60 & 62 & pT3bpN0M1G2 & 1 & Cytokine & Lung \\
\hline MR-6 & $\mathrm{M}$ & 61 & 61 & pT3bNxM1G2 & 2 & - & Bone \\
\hline MR-7 & $\mathrm{M}$ & 52 & 64 & pT2pNOM0G2 & 1 & - & Pleura, LN, local recurrence \\
\hline MR-8 & $\mathrm{M}$ & 32 & 43 & pT2pN0M0G2 & 2 & Cytokine & Lung, adrenal gland \\
\hline MR-9 & $\mathrm{F}$ & 67 & 68 & pT1pN0M1G2 & 2 & Cytokine & Lung, pancreas \\
\hline MR-10 & $\mathrm{F}$ & 60 & 65 & pT2NxM0G1 & 0 & Sorafenib & Lung \\
\hline MR-11 & $\mathrm{M}$ & 46 & 49 & pT3bNxM1G2 & 2 & $\mathrm{G} 250$ & Lung, LN, spinal cord \\
\hline MR-12 & $\mathrm{F}$ & 47 & 48 & pT1pN2M1G3 & 3 & Cytokine & Lung, LN, bone \\
\hline MR-13 & $\mathrm{M}$ & 50 & 54 & pT1pN0M0G2 & 1 & Vaccine $^{\mathrm{d}}$ & Lung, LN, brain \\
\hline MR-14 & $\mathrm{M}$ & 61 & 61 & pT3apN0M1G3 & 2 & Vaccine & Lung, LN, adrenal gland \\
\hline MR-15 & $\mathrm{M}$ & 50 & 58 & pT2NxM1G2 & 1 & Cytokine & Lung, LN \\
\hline
\end{tabular}

Abbreviations: F, female; LN, lymph node; M, male; TNMG: tumor size, node involvement, metastasis, grade.

${ }^{a}$ Score from 0 (very low risk) to 3 (high risk); based on performance status, number of metastatic sites, and time from first diagnosis to study entry (Palmer et al., 1992)

${ }^{\mathrm{b}}$ Cytokine: interferon- $\alpha$, interleukin-2, 5-fluorouracil.

${ }^{c}$ G250: monoclonal antibody directed against carbonic anhydrase-9.

${ }^{\mathrm{d}}$ Vaccine: multipeptide vaccine or dendritic cell vaccine.

status (ECOG scores of 0 or 1). Patients were also evaluated for prognosis according to the Palmer scoring criteria (Palmer et al., 1992). Seven patients had good scores of 0 or 1 , whereas eight patients were classified with poor scores of 2 or 3, according to the designated criteria of performance status, number of metastatic sites, and time from first diagnosis to study entry.

The primary tumors of all patients were surgically removed at the time of primary tumor diagnosis. Ten patients were treated subsequently with some form of immunotherapy, with the majority receiving cytokine therapy in the form of subcutaneous IFN- $\alpha$ and IL-2, with or without 5-fluorouracil. Three patients received anti-G250 antibody therapy and one patient was treated with the multi-tyrosine kinase inhibitor sorafenib, which was stopped after only a few days because of severe skin reactions. Two patients were included in previous vaccine trials using either tumor lysate-pulsed dendritic cells (Holtl et al., 2005) or a pool of HLA-A2-restricted, tumorassociated peptides.

\section{Vaccination schedule and clinical outcome}

Figure $1 \mathrm{~A}$ shows the vaccine dose and time schedule as well as points of clinical restaging, measurement of DTH reactions, and acquisition of samples for subsequent immune monitoring. The vaccination course for individual patients and various parameters of clinical outcome are summarized in Table 2. There was no difference in outcome between the four patients (MR-6, MR-7, MR-8, and MR-9) who received the short vaccination schedule that excluded the four lowdose vaccinations and the remaining patients. Patient MR-3 died 1 week after the second vaccination but no causal relationship was found between vaccination and death in this elderly patient. Patient MR-11 died in study week 17, 3 weeks after receipt of the eighth vaccine application. This patient had stable disease at the previous restaging accord- ing to RECIST criteria, and there was no evidence of a causal relationship with vaccination.

No remissions were observed in any patient according to RECIST criteria. In various patients tumor progression occurred at various sites, including the appearance of new lesions in the brain, bone, liver, adrenal glands, and lymph nodes in various individuals. Interestingly, progression of lung metastases was detected in only one instance and this patient showed a slow progression course (MR-4). At the end of the 36-week study period, $60 \%$ of the patients were alive. The median time to progression was 5.3 months (Fig. 1B). The median tumor-specific survival time was 15.6 months (Fig. 1C) and two patients are still alive to date, 24 and 35 months after study entry.

\section{Analysis of safety and toxicity}

The vaccine was well tolerated and no patient was withdrawn from the study because of side effects. The most common side effects noted were erythema, induration, and pruritus for a few days at the vaccine injection sites or DTH challenge sites. In most cases these responses occurred only after four or more vaccine applications. No local or systemic therapy was needed for treatment of adverse events in any study patient. In most cases, routine blood parameters (e.g., differential blood count, creatinine, electrolytes, and transaminases) showed no significant changes during the entire study period. Four patients (MR-9, MR-13, MR-14, and MR15) showed transient increases in $\alpha$-amylase and/or lipase, reaching up to 5-fold upper reference levels, with complete normalization after several weeks. The earliest detection of enzyme increase was after the fifth vaccination, when the vaccine dose was increased to $10 \times 10^{6}$ cells and vaccination applications were given at 2-week intervals (Fig. 1D). Further increases were not detected when the highest vaccine doses were applied at 4 -week intervals. The enzyme increases were 
A

\begin{tabular}{|c|c|c|c|c|c|c|c|c|c|c|c|c|}
\hline study week & 1 & 2 & 4 & 6 & 8 & 10 & 12 & 14 & 18 & 22 & 24 & 36 \\
\hline \multicolumn{13}{|l|}{$\begin{array}{l}\text { physical } \\
\text { examination }\end{array}$} \\
\hline \multicolumn{13}{|l|}{$\begin{array}{l}\text { routine blood } \\
\text { control }\end{array}$} \\
\hline \multicolumn{13}{|l|}{$\begin{array}{l}\text { blood sample for } \\
\text { immune monitoring }\end{array}$} \\
\hline \multicolumn{13}{|l|}{ DTH reactivity } \\
\hline \multicolumn{13}{|l|}{$\begin{array}{l}\text { computer } \\
\text { tomography }\end{array}$} \\
\hline bone scan & & & & & & & & & & & $\nLeftarrow$ & $\nLeftarrow$ \\
\hline vaccination & 0 & $\mathrm{O}$ & $\mathrm{O}$ & 0 & $\mathrm{O}$ & 0 & 0 & 0 & & & & \\
\hline
\end{tabular}

only when pathological findings in first examination, $\bigcirc_{2.5} \times 10^{6}$ cells, $\bigcirc 10 \times 10^{6}$ cells, $40 \times 10^{6}$ cells
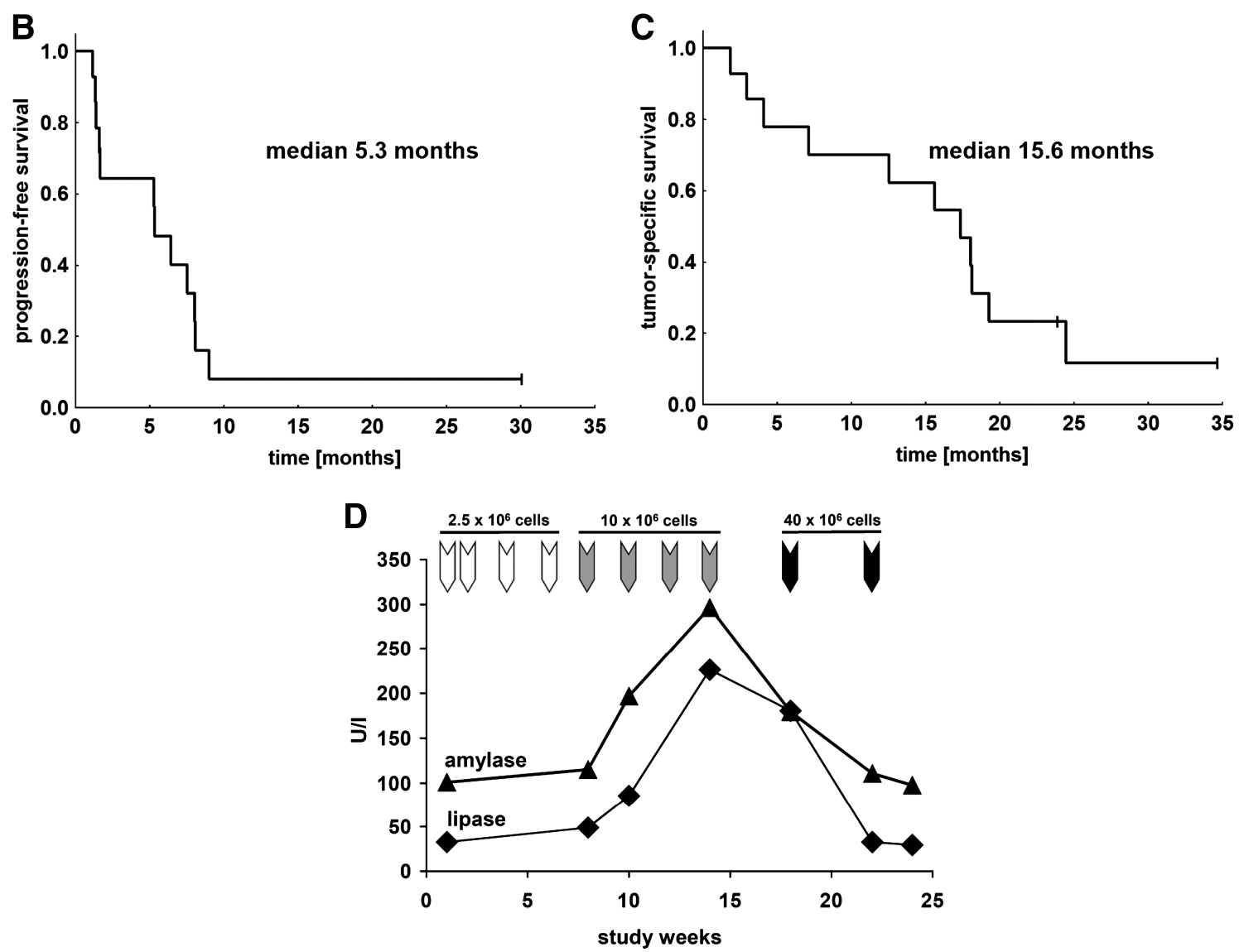

FIG. 1. (A) Time schedule of the vaccine study. (B) Kaplan-Meier plot of time to progression, with a median of 5.3 months. (C) Kaplan-Meier plot of tumor-specific survival, with median of 15.6 months. (D) Pancreatic enzyme changes during vaccination. An example is shown of the transient increases in amylase and lipase during the vaccination course of patient MR-14. The values are given as units per liter on the $y$ axis over the study course in weeks on the $x$ axis. The arrows indicate the times of vaccination at the three dose levels. 
Table 2. Vaccine Doses Delivered and Clinical Outcome

\begin{tabular}{|c|c|c|c|c|c|c|c|}
\hline$I D$ & $\begin{array}{c}2.5 \times 10^{6} \\
\text { cells }\end{array}$ & $\begin{array}{c}10 \times 10^{6} \\
\text { cells }\end{array}$ & $\begin{array}{c}40 \times 10^{6} \\
\text { cells }\end{array}$ & $\begin{array}{c}\text { Time to } \\
\text { progression (weeks) }\end{array}$ & $\begin{array}{c}\text { Site(s) of } \\
\text { progression }\end{array}$ & $\begin{array}{l}\text { Survival time } \\
\text { (weeks) }\end{array}$ & $\begin{array}{c}\text { Survival status at } \\
\text { study end }\end{array}$ \\
\hline MR-1 & 4 & 1 & - & 7 & Bone, brain ${ }^{\mathrm{a}}$ & 31 & DOD \\
\hline MR-2 & 4 & 4 & 2 & 23 & Pleura, bone ${ }^{a}$ & 79 & DOD \\
\hline MR-3 & 2 & - & - & - & - & 2 & Dead, not related to therapy/disease \\
\hline MR-4 & 4 & 4 & 2 & 35 & Lung & 68 & DOD \\
\hline MR-5 & 4 & 4 & 2 & 7 & $\mathrm{LN}^{\mathrm{a}}$ adrenal gland ${ }^{\mathrm{a}}$ & 76 & DOD \\
\hline MR-6 & - & 4 & - & 6 & Bone & 18 & DOD \\
\hline MR-7 & - & 4 & 2 & 28 & Pleura, liver ${ }^{a}$ & 84 & DOD \\
\hline MR-8 & - & 3 & - & 6 & Peritoneum & 13 & DOD \\
\hline MR-9 & - & 4 & 2 & 39 & Pancreas, liver ${ }^{\mathrm{a}}$ & 79 & DOD \\
\hline MR-10 & 4 & 4 & 2 & 23 & Brain $^{\mathrm{a}}$ & 55 & DOD \\
\hline MR-11 & 4 & 4 & - & $7^{\mathrm{b}}$ & - & 17 & Dead, not related to therapy/disease \\
\hline MR-12 & 4 & - & - & 5 & Bone & 8 & DOD \\
\hline MR-13 & 4 & 4 & 2 & 33 & Brain & 104 & Alive \\
\hline MR-14 & 4 & 4 & 2 & 35 & LN & 107 & DOD \\
\hline MR-15 & 4 & 4 & 2 & $131^{\mathrm{b}}$ & - & 151 & Alive \\
\hline
\end{tabular}

Abbreviations: DOD, dead of disease.

aNew metastases.

${ }^{\mathrm{b}}$ Stable disease at this time.

not accompanied by clinical symptoms and additional clinical examination revealed no evidence of pancreatitis. Moreover, no patient showed evidence of clinically relevant autoimmunity, as assessed by standard laboratory parameters.

\section{Immunological assessment of vaccine responses in vivo}

DTH reactions were detected in 11 of 12 evaluated patients after challenge with vaccine cells applied intradermally in the inguinal region at weeks 6, 14, and 22. Furthermore, most patients reported similar reactions at the sites of regular vaccine injections, first appearing after the receipt of at least three vaccine applications. The DTH challenge reactions were first assessed after patients had received four vaccine applications. Subsequent DTH challenge reactions increased in size and intensity with further vaccination. Reactions always disappeared within a few days and did not require medical intervention. Patient MR-6 failed to develop a DTH response even though he received four vaccine applications.

\section{Immune monitoring of lymphocyte responses ex vivo}

Sequential patient peripheral blood samples (see Fig. 1A) were obtained throughout the study period and IFN- $\gamma$ ELISPOT analyses were performed to compare lymphocyte responses to a variety of stimuli before and after vaccination. These studies were performed with various numbers of samples from 12 patients, dependent on the course of vaccination completed by each individual. Data were not available for patients MR-3, MR-8, and MR-12, who did not reach the time point for obtaining the first immune monitoring sample after four vaccine applications at either the low or intermediate cell doses (see Table 2 and Fig. 1A).

To determine the general capacity of patient PBMCs to respond to antigenic stimulation, IFN- $\gamma$ responses were assayed with a pool of HLA-A2-restricted viral peptides derived from proteins of cytomegalovirus, Epstein-Barr virus, and influenza virus, designated as the CEF peptide pool. Most HLA-A2 healthy donors have some memory T cells that respond to at least one of the peptides included in this

FIG. 2. Monitoring of immune responses by ELISPOT to vaccine lysate and surrogate peptides and peptide pools. (A) IFN- $\gamma$ ELISPOT results of PBMC samples obtained pre- and postvaccination of 12 patients after stimulation with vaccine cell lysates. Increased immune responses were detected in nine patients after vaccination: median, mean, and range are given as spots per $1.5 \times 10^{5}$ PBMCs obtained before the start of vaccination (pre) and the maximal response detected at any time point after at least four vaccine applications (post). Delta $(\Delta)$ values represent differences between prevaccine responses and postvaccination responses, using the highest response measured at any time point after at least four vaccine applications. (B) Responses to peptides derived from the candidate TAAs designated in Fig. 3. Tested were two pools of peptides (pools B and D) and four single peptides, giving a total of six stimuli that were used to activate patient PBMCs obtained pre- and postvaccination. Summarized are the numbers of patients whose PBMCs showed positive ELISPOT responses to none or to one to six of the various pools/peptides at any time after four vaccine applications as compared with prevaccination values. The actual ELISPOT data are given in Table 3. (C) Numbers of patients responding to the four single peptides compared with the levels of TAA overexpression in the vaccine cells, as quantified by qRT-PCR. TAA overexpression (mean value) is based on crossing-point analysis of the vaccine RCC-26/CD80/IL-2 cells as compared with a pool of five commercially obtained RNAs of normal kidney tissue as follows:,$++ 16-$ to 63 -fold;,$+++ 64-$ to 256 -fold;,$++++>256$-fold. ADFP, adipophilin (adipose differentiation-related protein). (D and E) Representative examples of ELISPOT results of patients MR-2 and MR-4 to (D) four single peptides and (E) peptide pools B and D. Data are presented as numbers of IFN- $\gamma$-secreting cells (spots) per $1.5 \times 10^{5}$ cells ( $y$ axis) over the study week course ( $x$ axis). 

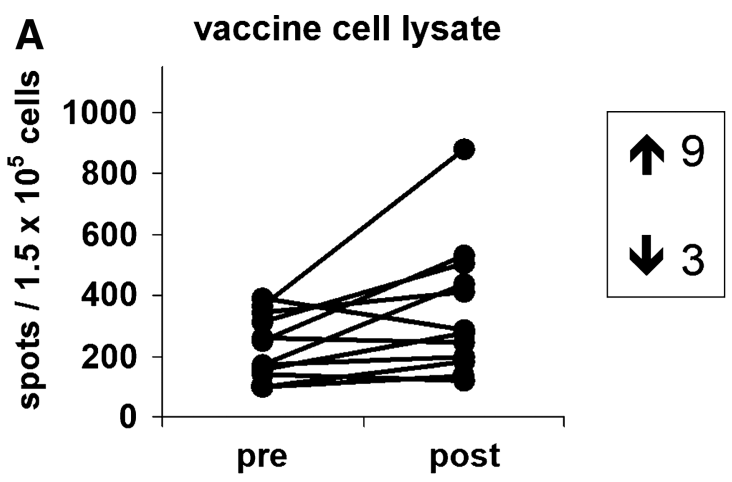

\begin{tabular}{|lll|}
\hline \multicolumn{2}{|c}{ positive immune responses $(\mathrm{n}=9)$} & \\
pre & post \\
median & 173 & 413 \\
mean & 218 & 396 \\
range & $98-364$ & $137-880$
\end{tabular}

$\begin{array}{lc}\Delta \text { positive immune responses }(n=9) \\ \text { median } & 120 \\ \text { mean } & 177 \\ \text { range } & 26-516\end{array}$
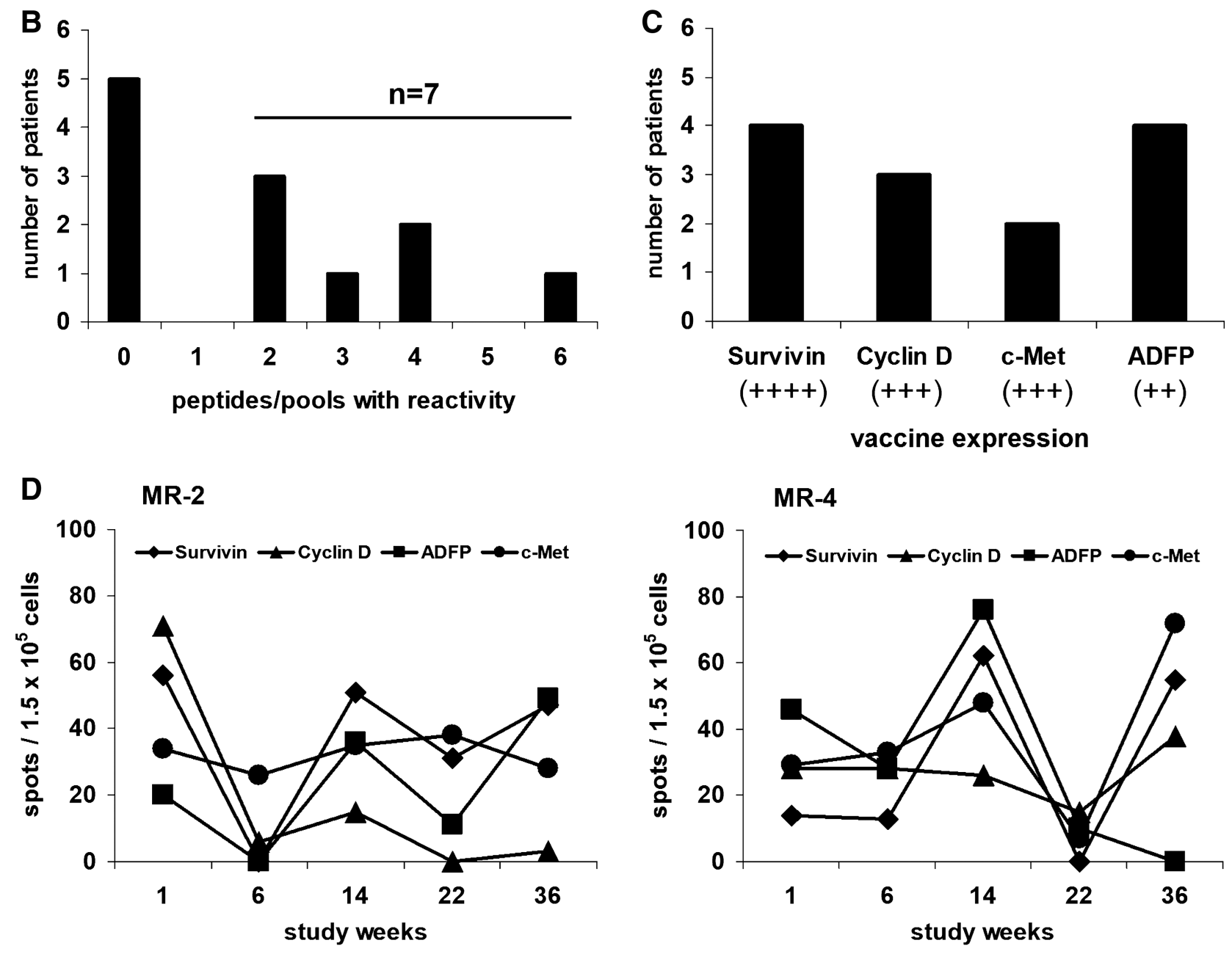

E MR-2
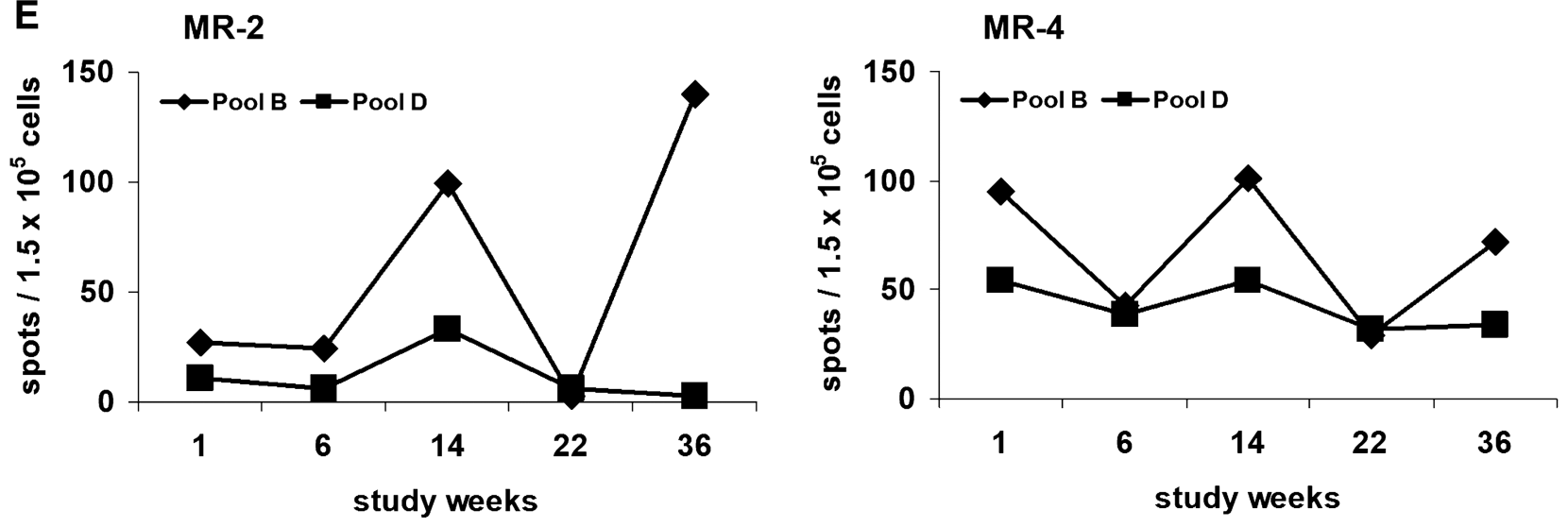
pool (Currier et al., 2002). Responses to CEF peptides were detected in prevaccination samples of all 12 patients (data not shown). Positive responses to CEF peptides were also detected in 37 of 38 patient blood samples obtained postvaccination, indicating that overt immune suppression capable of blocking all capacity for memory immune responses did not occur despite disease progression in most patients. However, five of nine patients evaluated 22 or 36 weeks after study entry did show substantial decreases in the magnitude of their CEF responses (data not shown). This, however, was not indicative of a shorter period of time to progression.

Vaccine cell lysates were used to determine immune reactivity as a whole to vaccine-associated determinants (Fig. 2A). Interestingly, several patients showed substantial responses to vaccine lysates in PBMCs obtained before vaccination. Nevertheless, the median and mean ELISPOT responses in nine patients increased substantially in the postvaccination samples in comparison with prevaccination levels. The median and mean differences between the preand postvaccination responses of the nine immune responders were determined and depicted as delta $(\Delta)$ values. This revealed a mean change of 177 spots, with a median of 120 in the nine responding patients (Fig. 2A).

To determine whether TAA-specific responses were induced as a result of vaccination, ELISPOT responses were tested with a panel of surrogate peptides derived from TAAs that are prevalent in RCC or other tumors. The TAAs used for this analysis were tested for their prevalence and expression levels, using a microarray analysis of $32 \mathrm{mRCC}$ lesions derived from a local tissue biorepository. RCC-26 cells were also included in this analysis (Fig. 3). All but one of the selected TAAs were expressed in the majority of tumor samples. Several TAAs were expressed in metastatic lesions but were not detected in RCC-26 cells. Nevertheless, they were included for future studies assessing epitope spreading. Several TAAs that were negative or poorly expressed in tumor samples and not expressed in RCC-26 cells were included as negative controls. It was not possible to perform similar array studies with patient tumors because the patients were recruited from throughout Germany and most entered the study several years after their primary diagnosis. Therefore, cryopreserved archival material was not available and for ethical reasons the protocol did not allow new biopsies to be made from the lung, bone, or liver metastases of these patients with advanced disease. Nevertheless, the analysis of metastatic RCC lesions obtained from the local tissue biorepository showed broad expression of most TAA candidates in a representative $\mathrm{mRCC}$ patient population.

The immune-monitoring peptides derived from these 17 TAAs all carried anchor residues that allowed them to be presented by autologous HLA-A2 molecules (see Materials and Methods). Because of the high number of peptides to be evaluated, pools B and D, which contained multiple peptides, were created. Subsequent to vaccination, the responses of individual patients varied over time and various patients showed prominent responses to the two pools. Representative responses are summarized in Table 3, in which prevaccine values are juxtaposed to the strongest recorded responses detected at any time point postvaccination. An HLA-A2-restricted peptide derived from the Bcr/Abl fusion protein (Yotnda et al., 1998) was used as a background control and only low numbers of spots (median, 0 spots; range, 0 to 29 spots) were detected in pre- and postvaccination samples (data not shown). $\mathrm{T}$ cell responses were also measured against four single peptides, survivin, cyclin D1, adipophilin (adipose differentiation-related protein [ADFP]), and c-Met, which were shown previously by others to be associated with $\mathrm{T}$ cell reactivity in patients with RCC

\begin{tabular}{|l|c|c|c|}
\cline { 2 - 4 } \multicolumn{1}{c|}{} & \multicolumn{2}{c|}{ Metastatic lesions } & RCC-26 \\
\cline { 2 - 4 } \multicolumn{1}{c|}{} & $\begin{array}{c}\text { \% positive } \\
\text { samples }\end{array}$ & $\begin{array}{c}\text { expression } \\
\text { level }\end{array}$ & $\begin{array}{c}\text { expression } \\
\text { level }\end{array}$ \\
\hline Single peptides & & & \\
Cyclin D1 & 100 & +++ & +++ \\
C-MET & 100 & +++ & +++ \\
ADFP & 100 & +++ & +++ \\
Survivin & 84 & ++ & +++ \\
Pool B & & & \\
OFA & & & \\
RGS5 & 100 & +++ & ++ \\
PRUNE2 & 100 & ++ & + \\
MUC-1 & 97 & +++ & - \\
Apolipoprotein & 94 & +++ & ++ \\
hTERT & 84 & ++ & +++ \\
Pool D & 3 & + & - \\
VEGF & & & \\
Her2/neu & & & ++ \\
WT-1 & 100 & +++ & + \\
MAGE-A1 & 81 & ++ & - \\
MAGE-A5 & 69 & ++ & - \\
MAGE-A3 & 6 & ++ & - \\
NYESO & 6 & + & + \\
\hline
\end{tabular}

FIG. 3. Expression of tumor-associated antigens in metastatic RCC lesions and RCC-26 cells. Given are percentages of samples positive for selected candidate antigens in a panel of 32 metastatic RCC lesions and normalized levels of antigen expression in microdissected tumor cells from the metastatic lesions and in RCC-26 cells as determined by microarray analysis. The scale for the model-based expression index is as follows:,- no expression;,$+<100 ;++, 100-999 ;+++, \geq 1000$. 
Table 3. Absolute Numbers of Peptide-Reactive T Cells in Peripheral Blood (per $1.5 \times 10^{5}$ Cells Pre/postvaccination)

\begin{tabular}{|c|c|c|c|c|c|c|c|c|c|}
\hline$I D$ & DTH & Pool $B^{\mathrm{a}}$ & Pool $D^{\mathrm{b}}$ & Survivin & Cyclin D1 & $A D F P$ & $c-M e t$ & $\begin{array}{c}\text { Time to progression } \\
\text { (weeks) }\end{array}$ & $\begin{array}{l}\text { Survival } \\
\text { (weeks) }\end{array}$ \\
\hline MR-1 & + & $44 / 66^{\mathrm{c}}$ & $93 / 59$ & $-/-^{\mathrm{d}}$ & $12 /-$ & $25 /-$ & $49 /-$ & 7 & 31 \\
\hline MR-2 & + & $27 / 140^{\mathrm{e}}$ & $11 / 33$ & $56 / 51$ & $71 / 15$ & $20 / 85$ & $34 / 65$ & 23 & 79 \\
\hline MR-4 & + & $95 / 101$ & $54 / 54$ & $14 / 62$ & $28 / 38$ & $46 / 76$ & $29 / 72$ & 35 & 68 \\
\hline MR-5 & + & $51 / \mathbf{1 2 4}$ & $17 / 33$ & $-/ 25$ & $-/ 33$ & $-/ 35$ & $-/ 47$ & 7 & 76 \\
\hline$M R-6^{f}$ & - & $-/ 19$ & $-/-$ & $14 /-$ & $13 /-$ & $14 /-$ & $35 /-$ & 6 & 18 \\
\hline MR-7 $7^{\mathrm{f}}$ & + & $39 / \mathbf{1 7 3}$ & $-/ 41$ & $16 /-$ & $-/-$ & $-1-$ & $-/-$ & 28 & 84 \\
\hline$M R-9^{f}$ & + & $34 / 44$ & $29 / 34$ & $18 /-$ & $12 /-$ & $-/ 11$ & $12 / 14$ & 39 & 79 \\
\hline MR-10 & + & $97 / 104$ & $71 / 75$ & $81 /-$ & $-/ 15$ & $43 / 23$ & $20 /-$ & 23 & 55 \\
\hline MR-11 & + & $141 / 150$ & 75/171 & $-/ 29$ & $-1-$ & $-/-$ & $-/-$ & $\mathrm{SD}(7)^{\mathrm{g}}$ & 17 \\
\hline MR-13 & + & $98 / 114$ & $108 / 161$ & $-/ 12$ & $-/-$ & $34 /-$ & $20 /-$ & 33 & 104 (alive) \\
\hline MR-14 & + & $13 / 75$ & $-/ 24$ & $17 / 32$ & $-/ 59$ & $-/ 35$ & $-/ 19$ & 35 & 107 \\
\hline MR-15 & + & $-/ 57$ & $-/ 41$ & $-/ 26$ & $24 / 30$ & $-/ 25$ & $19 / 24$ & SD $(131)^{g}$ & 151 (alive) \\
\hline
\end{tabular}

Abbreviations: DTH, delayed-type hypersensitivity reaction; SD, stable disease.

aPool B contains the peptides for RGS-5, apolipoprotein, MUC-1, OFA, hTERT, and KIAA0367 (PRUNE2).

${ }^{b}$ Pool D contains the peptides for VEGF, NY-ESO, Her2/neu, MAGE-1, $-3,-6$, and WT-1.

${ }^{c}$ The values represent absolute numbers of spots for pre- and postvaccination (pre/post) responses. These values are given after subtraction of background responses (i.e., without peptide or with irrelevant Bcr/Abl peptide). The highest postvaccination response is given irrespective of the time point postvaccination (i.e., at $6,14,22$, or 36 weeks).

${ }^{\mathrm{d}}$ No values mean no reactivity ( $\leq 10$ Spots above background, which corresponds to a frequency of $\leq 1 / 1.5 \times 10^{4}$ IFN- $\gamma$-secreting peptidespecific T cells).

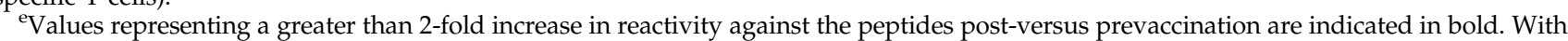
the larger peptide pools a reactivity of $\geq 40$ spots above background was considered positive.

${ }^{\mathrm{f}}$ Short protocol of vaccination starting with the middle dose of $10^{7}$ vaccine cells.

${ }^{\mathrm{g} S D}$ (7) and SD (131) indicate stable disease at weeks 7 and 131, respectively.

(Stevanovic, 2002). Seven of 12 patients showed responses to either the single peptides and/or the pools, with all seven immune responders showing responses to two or more peptides/pools that were greater than 2 -fold compared with prevaccination values (Fig. $2 \mathrm{~B}$ ). It should be noted that most patients showed substantial prevaccination responses to one or both pools and several of the single peptides, indicating that their PBMCs contained effector memory cells. The TAAs from which the four single peptides were derived showed variations in mRNA expression levels in the vaccine cells, but this did not impact on the number of patients capable of responding to the individual peptides (Fig. 2C). The time courses of responses to the single peptides and pools $\mathrm{B}$ and D are illustrated for two representative patients (Fig. 2D and E). In general, responses to the individual stimuli (pools or single peptides) showed similar patterns of increase or decrease throughout the vaccine schedule.

\section{Discussion}

Individualized RCC cell vaccines offer the possibility to target immune responses to a unique array of epitopes that arise through genetic mutation in tumor cells; however, a parallel compensation must be made to improve the inferior immune-stimulatory capacity of tumor cells. Today, preparation of patient-individualized tumor vaccines entails obtaining tumor samples from individual patients, genetically engineering them under stringent GMP conditions, and performing quality assurance studies to demonstrate that sufficient numbers of cells show adequate levels of gene expression to achieve the desired immune effects. Combined, all of these steps require substantial amounts of time, result in high costs, and yield potential limitations in vaccine availability for individual patients, particularly if multiple vaccine applications with large numbers of cells are deemed to be beneficial.

Our vaccine strategy was designed to overcome these logistical hurdles by relying on the use of a generic vaccine that could be applied in multiple patients. For vaccine development, we used a well-characterized RCC-26 tumor cell line that showed strong immunogenic potential in extensive preclinical studies (Schendel and Gansbacher, 1993; Schendel et al., 1993, 2000; Frankenberger et al., 2005a,b). This inherent immune-stimulatory potential was improved through gene modification to allow the RCC-26 cells to express surface CD80 molecules in order to improve their capacity to induce $\mathrm{T}$ cell responses through provision of secondary activation signals to responding lymphocytes. This strategy was supported by our preclinical experimental mouse tumor models, which clearly demonstrated that CD80 expression on tumor cells induced cytotoxic $\mathrm{T}$ lymphocytes by direct priming (Cayeux et al., 1997). Furthermore, CD80 expression on RCC26 cells supported reactivation of effector memory $\mathrm{T}$ cells that were present in patients with RCC (Schendel et al., 2000).

Gene modification of RCC-26 cells to secrete IL-2 was chosen because of the well-known clinical benefits of IL-2 achieved in some patients with RCC by systemic therapy (Rosenberg, 2007). Our vaccine cells secreted only low levels of IL-2 ( $8 \mathrm{ng}$ of IL-2 per $10^{6}$ cells per $24 \mathrm{hr}$ ) and thus systemic effects were not expected. In fact, it was shown previously that the amount of IL-2 produced by vaccine cells has a strong impact on the generation of tumor immunity. If vaccine cells released high amounts of IL-2, tumor immunity could be completely abrogated (Schmidt et al., 1995). Our preclinical studies of IL-2-modified RCC-26 cells showed clearly that low levels of IL-2 could indeed specifically support activation of effector memory cells. This was manifested in the remobilized effector lymphocytes by increased 
proliferation, enhanced cytotoxic function against tumor cells, and improved survival through upregulation of antiapoptosis genes in the remobilized effector lymphocytes (Frankenberger et al., 2005b). Furthermore, IL-2 expression by the vaccine cells supported the activation of natural killer cells (Schendel and Gansbacher, 1993).

Moreover, the vaccine cells could further impact the development of immune responses through their capacity to induce alloresponses due to expression of mismatched HLA allotypes with study patients, providing a rich cytokine milieu as well as nonspecific help through recruitment of $\mathrm{CD}^{+}$ $\mathrm{T}$ cells that could support the development of antitumor immunity (Schendel et al., 2000). We showed previously that ongoing alloresponses stimulated by the vaccine cells did not suppress $\mathrm{T}$ cell responses to RCC-associated epitopes (Frankenberger et al., 2005a).

Because this was a generic vaccine designed for use in patients who expressed the HLA-A*0201 allotype, only one vaccine development phase was needed. This allowed extensive characterization of the vaccine cells postproduction according to GMP standards to certify that the genetically engineered cells presented excellent characteristics with respect to gene expression and immunological function (Frankenberger et al., 2005a). Thereafter, there were no time constraints for patient use and the amount of vaccine was not a limiting factor. The vaccine cells were available in an irradiated, cryopreserved formulation that allowed direct application to patients without manipulation after thawing. The clinical status of the patient was the primary factor that influenced the number of vaccine applications that could be delivered during the study period.

Because only one tumor cell line was employed, it was also possible to carry out extensive studies regarding expression of a variety of TAAs in the vaccine cells. This allowed the identification of a series of TAAs that were overexpressed in RCC-26 cells and made it possible to devise specific immune-monitoring tools to study the induction or reactivation of TAA-specific T cells. Surrogate peptides, representing epitopes derived from several overexpressed TAAs, were selected for their capacity to be presented by HLA-A2 molecules. They were tested either in pools or as single peptides to measure $\mathrm{T}$ cell responses in patients throughout the study course. This enabled several parameters of response to be assessed, providing a better picture of the development of specific immune responses generated through vaccination in the study group.

This form of tumor cell vaccination was found to be feasible and safe. The designated vaccine course was completed in 9 of 15 patients. Despite heavy tumor burdens at study entry, seven patients completed a vaccination schedule spanning 22 weeks. The majority of patients had multiple metastases at two or more sites at enrollment, and more than half of the patients had poor prognosis scores according to Palmer and colleagues (1992), revealing their advanced states of disease. Those patients who progressed too rapidly to complete the vaccine protocol had poor prognosis scores of 2 or 3 , according to the criteria of Palmer and colleagues.

The vaccine was also determined to be safe, even when applied at doses of $40 \times 10^{6}$ cells. Although vaccine site reactions and DTH challenge reactions increased in magnitude with increasing vaccine applications, this did not prohibit
10 vaccine applications in the course of 22 weeks. These responses were transient, disappeared within a few days, and did not require medical intervention. The most serious vaccine-associated toxicity was the transient increase in amylase and lipase enzyme levels in four patients. These increases were first detected after the fifth vaccine injection. They increased during the subsequent vaccine applications given at 2-week intervals but then disappeared, despite further increases in cell dose. Thus, these transient increases seemed to be related more to the time interval between vaccine applications than to cell dose. These increases were not accompanied by other systemic symptoms and signs of pancreatitis were not detected by clinical examination, imaging, and measurement of additional blood parameters. Development of autoimmunity was assessed by the appearance of anti-nuclear antibodies and rheumatoid factor or changes in complement factors. No relevant changes were noted in any patient throughout the study course.

All patients had progressive disease before they entered the study, except one patient (MR-14) who was enrolled previously in a peptide vaccine trial (A. Buchner, unpublished observation). Of the 14 progressing patients, half showed stable disease for time periods ranging from 23 to 131 weeks. The median time to progression was 5.3 months and the median tumor-specific survival time was 15.6 months. Interestingly, studies of much larger groups of patients showed progression-free survival times of 5.5 months with the angiogenesis inhibitor sorafenib (Escudier et al., 2007) and 5 months with IFN- $\alpha$ (Motzer et al., 2007); however, the side effects of these therapies were much greater. Progression was detected at various sites and new lesions appeared in various organs. It should be noted that although 13 patients had lung metastases at study entry, further tumor progression at this site was observed in only 1 patient (MR4). In addition, the progression of multiple lung lesions in this patient was slow. It has been observed in other studies that lung metastases may respond better to immunotherapies than metastases at other sites (Han et al., 2003).

Immune monitoring revealed that vaccine-induced $\mathrm{T}$ cell responses could be detected in a majority of the patients. Strong reactivity to the control viral CEF pool was detected in prevaccination samples of all evaluated patients, indicating that their memory $\mathrm{T}$ cells were capable of responding to antigenic stimulation despite extensive tumor burden that is often associated with a general state of immune suppression (Frankenberger et al., 2007). Responses to CEF peptides were retained in seven of nine patients postvaccination at 22 weeks. However, spot numbers were lower in three patients at 36 weeks compared with values obtained at weeks 1, 6, and 14, indicating some loss of immune potential. There were also surprisingly high responses to vaccine lysates in the prevaccination samples and these increased in nine patients through vaccination. Because the responding lymphocytes in the ELISPOT assays were not separated into natural killer (NK) and $\mathrm{T}$ cell fractions, it is possible that some of this reactivity was due to NK cells, which were shown previously to respond to RCC-26 cells in the presence of IL-2 (Schendel et al., 2000; Falk et al., 2002; Frankenberger et al., 2005b). On the other hand, there is substantial evidence that patients with RCC spontaneously develop $\mathrm{T}$ cell responses to their tumors. Thus, some of the response to lysate stimulation may reflect responses of effector memory $\mathrm{T}$ cells. 
Because RCC-26 cells overexpress a large number of various TAAs, such $\mathrm{T}$ cell responses may be specific for TAAs that are shared by various RCCs. Further evidence of the presence of preexisting effector memory $\mathrm{T}$ cells in some patients was reflected in the ELISPOT responses detected to the pools and single peptides in prevaccine PBMCs.

More than half of the patients showed vaccinationassociated increases in T cell reactivity to surrogate peptides that were derived from TAAs overexpressed by the vaccine cells and commonly shared by RCC (Stevanovic, 2002). The patterns of response to the single peptides and peptide pools were diverse, indicating that an immunodominant epitope was not present in this set of surrogate peptides. Furthermore, several patients responded to two or more specific peptides or pools, indicating that several epitopes expressed by the vaccine cells could elicit ELISPOT responses in these patients with advanced disease. However, no correlation was found between degree of immune response and stabilization of disease as reflected by time to progression or survival times. Further studies are needed to elucidate the individual specificity of responses occurring to the two peptide pools. This will then provide a more complete picture of the specificity and complexity of $\mathrm{T}$ cell responses, including the role of epitope spreading, occurring as a result of vaccination.

Although no clinical responses according to RECIST were detected, the median survival time seen in this small patient group was long, considering their clinical status at study entry. Because of the minimal side effects, vaccination was well tolerated and could be delivered on an outpatient basis throughout the study course. The use of a generic vaccine strategy for selected HLA-A*0201-positive patients contributed substantially to the feasibility of employing an escalating, multidose vaccine strategy because vaccine cells were not limiting. This generic approach also allowed a standardized immune-monitoring approach to be used for all study patients. On the basis of the preliminary results presented here, it can be concluded that the majority of patients acquired increased $\mathrm{T}$ cell reactivity through vaccination to several epitopes derived from shared TAAs. Such T cell responses may be able to elicit significant immune attacks against autologous tumor lesions in better clinical settings. This could include, for example, combining vaccination with the application of treatment strategies that reduce regulatory cells that can dampen ongoing immune responses. Furthermore, combination therapies employing vaccination and new molecular inhibitors to block tumor-driven angiogenesis and retard tumor progression may allow better immune responses to develop over longer periods of time.

The demonstrated feasibility of applying this vaccine in a group of patients at fairly low cost, with substantial savings in time and logistics as compared with individualized patient vaccines-alongside safety, low toxicity, and substantial immune-stimulatory potential-supports performing further evaluations of this vaccine in combination therapies and as adjuvant therapy in patients with minimal residual disease.

\section{Acknowledgments}

This study was supported by the Federal Ministry of Education and Research (01 GE 9624/1) and the German National Research Foundation (SFB-455 and SFB-TR36).
The authors thank Roswitha Fischer, Heidi Herbig, and Birgit Stadlbauer for excellent technical support in immune monitoring.

\section{Author Disclosure Statement}

No competing financial interests exist.

\section{References}

Antonia, S.J., Seigne, J., Diaz, J., Muro-Cacho, C., Extermann, M., Farmelo, M.J., Friberg, M., Alsarraj, M., Mahany, J.J., PowSang, J., Cantor, A., and Janssen, W. (2002). Phase I trial of a B7-1 (CD80) gene modified autologous tumor cell vaccine in combination with systemic interleukin-2 in patients with metastatic renal cell carcinoma. J. Urol. 167, 1995-2000.

Apostolopoulos, V., Karanikas, V., Haurum, J.S., and McKenzie, I.F. (1997). Induction of HLA-A2-restricted CTLs to the mucin 1 human breast cancer antigen. J. Immunol. 159, 5211-5218.

Brill, T.H., Kubler, H.R., von Randenborgh H., Fend, F., Pohla, H., Breul, J., Hartung, R., Paul, R., Schendel, D.J., and Gansbacher, B. (2007). Allogeneic retrovirally transduced, IL-2- and IFN- $\gamma$-secreting cancer cell vaccine in patients with hormone refractory prostate cancer: A phase I clinical trial. J. Gene Med. 9, 547-560.

Britten, C.M., Gouttefangeas, C., Welters, M.J., Pawelec, G., Koch, S., Ottensmeier, C., Mander, A., Walter, S., Paschen, A., Muller-Berghaus, J., Haas, I., Mackensen, A., Kollgaard, T., Thor, S.P., Schmitt, M., Giannopoulos, K., Maier, R., Veelken, H., Bertinetti, C., Konur, A., Huber, C., Stevanovic, S., Wolfel, T., and van der Burg, S.H. (2008). The CIMT-monitoring panel: A two-step approach to harmonize the enumeration of antigen-specific $\mathrm{CD}^{+} \mathrm{T}$ lymphocytes by structural and functional assays. Cancer Immunol. Immunother. 57, 289-302.

Brossart, P., Heinrich, K.S., Stuhler, G., Behnke, L., Reichardt, V.L., Stevanovic, S., Muhm, A., Rammensee, H.G., Kanz, L., and Brugger, W. (1999). Identification of HLA-A2-restricted Tcell epitopes derived from the MUC1 tumor antigen for broadly applicable vaccine therapies. Blood 93, 4309-4317.

Cayeux, S., Richter, G., Becker, C., Beck, C., Aicher, A., Pezzutto, A., Dörken, B., and Blankenstein, T. (1997). Lack of correlation between rejection of tumor cells co-expressing interleukin-2 and B7.1 and vaccine efficiency. Eur. J. Immunol. 27, 16571662.

Currier, J.R., Kuta, E.G., Turk, E., Earhart, L.B., Loomis-Price, L., Janetzki, S., Ferrari, G., Birx, D.L., and Cox, J.H. (2002). A panel of MHC class I restricted viral peptides for use as a quality control for vaccine trial ELISPOT assays. J. Immunol. Methods 260, 157-172.

Escudier, B., Eisen, T., Stadler, W.M., Szczylik, C., Oudard, S., Siebels, M., Negrier, S., Chevreau, C., Solska, E., Desai, A.A., Rolland, F., Demkow, T., Hutson, T.E., Gore, M., Freeman, S., Schwartz, B., Shan, M., Simantov, R., and Bukowski, R.M. (2007). Sorafenib in advanced clear-cell renal-cell carcinoma. N. Engl. J. Med. 356, 125-134.

Falk, C.S., Noessner, E., Weiss, E.H., and Schendel, D.J. (2002). Retaliation against tumor cells showing aberrant HLA expression using lymphokine activated killer-derived $\mathrm{T}$ cells. Cancer Res. 62, 480-487.

Fishman, M., Hunter, T.B., Soliman, H., Thompson, P., Dunn, M., Smilee, R., Farmelo, M.J., Noyes, D.R., Mahany, J.J., Lee, J.H., Cantor, A., Messina, J., Seigne, J., Pow-Sang, J., Janssen, W., and Antonia, S.J. (2008). Phase II trial of B7-1 (CD-86) transduced, cultured autologous tumor cell vaccine plus subcutaneous interleukin-2 for treatment of stage IV renal cell carcinoma. J. Immunother. 31, 72-80. 
Flad, T., Spengler, B., Kalbacher, H., Brossart, P., Baier, D., Kaufmann, R., Bold, P., Metzger, S., Bluggel, M., Meyer, H.E., Kurz, B., and Muller, C.A. (1998). Direct identification of major histocompatibility complex class I-bound tumor-associated peptide antigens of a renal carcinoma cell line by a novel mass spectrometric method. Cancer Res. 58, 5803-5811.

Frankenberger, B., Pohla, H., Noessner, E., Willimsky, G., Papier, B., Pezzutto, A., Kopp, J., Oberneder, R., Blankenstein, T., and Schendel, D.J. (2005a). Influence of CD80, interleukin-2, and interleukin-7 expression in human renal cell carcinoma on the expansion, function, and survival of tumor-specific CTLs. Clin. Cancer Res. 11, 1733-1742.

Frankenberger, B., Regn, S., Geiger, C., Noessner, E., Falk, C.S., Pohla, H., Javorovic, M., Silberzahn, T., Wilde, S., Buchner, A., Siebels, M., Oberneder, R., Willimsky, G., Pezzutto, A., Blankenstein, T., and Schendel, D.J. (2005b). Cell-based vaccines for renal cell carcinoma: Genetically-engineered tumor cells and monocyte-derived dendritic cells. World J. Urol. 23, 166174.

Frankenberger, B., Noessner, E., and Schendel, D.J. (2007). Immune suppression in renal cell carcinoma. Semin. Cancer Biol. 17, 330-343.

Gatz, S.A., Pohla, H., and Schendel, D.J. (2000). A PCR-SSP method to specifically select HLA-A*0201 individuals for immunotherapeutic studies. Tissue Antigens 55, 532-547.

Han, K.R., Pantuck, A.J., Bui, M.H., Shvarts, O., Freitas, D.G., Zisman, A., Leibovich, B.C., Dorey, F.J., Gitlitz, B.J., Figlin, R.A., and Belldegrun, A.S. (2003). Number of metastatic sites rather than location dictates overall survival of patients with node-negative metastatic renal cell carcinoma. Urology 61, 314-319.

Holtl, L., Ramoner, R., Zelle-Rieser, C., Gander, H., Putz, T., Papesh, C., Nussbaumer, W., Falkensammer, C., Bartsch, G., and Thurnher, M. (2005). Allogeneic dendritic cell vaccination against metastatic renal cell carcinoma with or without cyclophosphamide. Cancer Immunol. Immunother. 54, 663-670.

Jager, E., Chen, Y.T., Drijfhout, J.W., Karbach, J., Ringhoffer, M., Jager, D., Arand, M., Wada, H., Noguchi, Y., Stockert, E., Old, L.J., and Knuth, A. (1998). Simultaneous humoral and cellular immune response against cancer-testis antigen NY-ESO-1: Definition of human histocompatibility leukocyte antigen (HLA)-A2-binding peptide epitopes. J. Exp. Med. 187, 265-270.

Janetzki, S., Panageas, K.S., Ben-Porat, L., Boyer, J., Britten, C.M., Clay, T.M., Kalos, M., Maecker, H.T., Romero, P., Yuan, J., Kast, W.M., and Hoos, A. (2008). Results and harmonization guidelines from two large-scale international Elispot proficiency panels conducted by the Cancer Vaccine Consortium (CVC/SVI). Cancer Immunol. Immunother. 57, 303-315.

Janzen, N.K., Kim, H.L., Figlin, R.A., and Belldegrun, A.S. (2003). Surveillance after radical or partial nephrectomy for localized renal cell carcinoma and management of recurrent disease. Urol. Clin. North Am. 30, 843-852.

Kawashima, I., Hudson, S.J., Tsai, V., Southwood, S., Takesako, K., Appella, E., Sette, A., and Celis, E. (1998). The multi-epitope approach for immunotherapy for cancer: Identification of several CTL epitopes from various tumor-associated antigens expressed on solid epithelial tumors. Hum. Immunol. 59, 1-14.

Kim, H.L., Belldegrun, A.S., and Figlin, R.A. (2003). Immune gene therapy for kidney cancer: The search for a magic trigger. Mol. Ther. 7, 153-154.

Kruger, T., Schoor, O., Lemmel, C., Kraemer, B., Reichle, C., Dengjel, J., Weinschenk, T., Muller, M., Hennenlotter, J., Stenzl, A., Rammensee, H.G., and Stevanovic, S. (2005). Lessons to be learned from primary renal cell carcinomas: Novel tumor antigens and HLA ligands for immunotherapy. Cancer Immunol. Immunother. 54, 826-836.

Li, C., and Wong, W.H. (2001). Model-based analysis of oligonucleotide arrays: Expression index computation and outlier detection. Proc. Natl. Acad. Sci. U.S.A. 98, 31-36.

Longo, R., D'Andrea, M.R., Sarmiento, R., Salerno, F., and Gasparini, G. (2007). Integrated therapy of kidney cancer. Ann. Oncol. 18(Suppl. 6), vi141-vi148.

Mach, N., and Dranoff, G. (2000). Cytokine-secreting tumor cell vaccines. Curr. Opin. Immunol. 12, 571-575.

Minev, B., Hipp, J., Firat, H., Schmidt, J.D., Langlade-Demoyen, P., and Zanetti, M. (2000). Cytotoxic T cell immunity against telomerase reverse transcriptase in humans. Proc. Natl. Acad. Sci. U.S.A. 97, 4796-4801.

Motzer, R.J. (2003). Renal cell carcinoma: A priority malignancy for development and study of novel therapies. J. Clin. Oncol. 21, 1193-1194.

Motzer, R.J., Hutson, T.E., Tomczak, P., Michaelson, M.D., Bukowski, R.M., Rixe, O., Oudard, S., Negrier, S., Szczylik, C., Kim, S.T., Chen, I., Bycott, P.W., Baum, C.M., and Figlin, R.A. (2007). Sunitinib versus interferon alfa in metastatic renal-cell carcinoma. N. Engl. J. Med. 356, 115-124.

Oka, Y., Elisseeva, O.A., Tsuboi, A., Ogawa, H., Tamaki, H., Li, H., Oji, Y., Kim, E.H., Soma, T., Asada, M., Ueda, K., Maruya, E., Saji, H., Kishimoto, T., Udaka, K., and Sugiyama, H. (2000). Human cytotoxic T-lymphocyte responses specific for peptides of the wild-type Wilms' tumor gene (WT1) product. Immunogenetics 51, 99-107.

Otto, K., Andersen, M.H., Eggert, A., Keikavoussi, P., Pedersen, L.O., Rath, J.C., Bock, M., Brocker, E.B., Straten, P.T., Kampgen, E., and Becker, J.C. (2005). Lack of toxicity of therapyinduced $\mathrm{T}$ cell responses against the universal tumour antigen survivin. Vaccine 23, 884-889.

Palmer, P.A., Vinke, J., Philip, T., Negrier, S., Atzpodien, J., Kirchner, H., Oskam, R., and Franks, C.R. (1992). Prognostic factors for survival in patients with advanced renal cell carcinoma treated with recombinant interleukin-2. Ann. Oncol. 3, 475-480.

Pardoll, D.M. (1998). Cancer vaccines. Nat. Med. 4, 525-531.

Pascolo, S., Schirle, M., Guckel, B., Dumrese, T., Stumm, S., Kayser, S., Moris, A., Wallwiener, D., Rammensee, H.G., and Stevanovic, S. (2001). A MAGE-A1 HLA-A A*0201 epitope identified by mass spectrometry. Cancer Res. 61, 4072-4077.

Rosenberg, S.A. (2007). Interleukin 2 for patients with renal cancer. Nat. Clin. Pract. Oncol. 4, 497.

Sadovnikova, E., Jopling, L.A., Soo, K.S., and Stauss, H.J. (1998). Generation of human tumor-reactive cytotoxic T cells against peptides presented by non-self HLA class I molecules. Eur. J. Immunol. 28, 193-200.

Scardino, A., Alves, P., Gross, D. A., Tourdot, S., Graff-Dubois, S., Angevin, E., Firat, H., Chouaib, S., Lemonnier, F., Nadler, L.M., Cardoso, A.A., and Kosmatopoulos, K. (2001). Identification of HER-2/neu immunogenic epitopes presented by renal cell carcinoma and other human epithelial tumors. Eur. J. Immunol. 31, 3261-3270.

Schendel, D.J. (2007). Dendritic cell vaccine strategies for renal cell carcinoma. Expert Opin. Biol. Ther. 7, 221-232.

Schendel, D.J., and Gansbacher, B. (1993). Tumor-specific lysis of human renal cell carcinomas by tumor-infiltrating lymphocytes: Modulation of recognition through retroviral transduction of tumor cells with interleukin 2 complementary DNA and exogenous $\alpha$ interferon treatment. Cancer Res. 53, 4020-4025.

Schendel, D.J., Gansbacher, B., Oberneder, R., Kriegmair, M., Hofstetter, A., Riethmuller, G., and Segurado, O.G. (1993). 
Tumor-specific lysis of human renal cell carcinomas by tumorinfiltrating lymphocytes. I. HLA-A2-restricted recognition of autologous and allogeneic tumor lines. J. Immunol. 151, 42094220.

Schendel, D.J., Frankenberger, B., Jantzer, P., Cayeux, S., Nobetaner, E., Willimsky, G., Maget, B., Pohla, H., and Blankenstein, T. (2000). Expression of B7.1 (CD80) in a renal cell carcinoma line allows expansion of tumor-associated cytotoxic $\mathrm{T}$ lymphocytes in the presence of an alloresponse. Gene Ther. 7, 2007-2014.

Schmidt, W., Schweighoffer, T., Herbst, E., Maass, G., Berger, M., Schilcher, F., Schaffner, G., and Birnstiel, M.L. (1995). Cancer vaccines: The interleukin 2 dosage effect. Proc. Natl. Acad. Sci. U.S.A. 92, 4711-4714.

Schmitz, M., Diestelkoetter, P., Weigle, B., Schmachtenberg, F., Stevanovic, S., Ockert, D., Rammensee, H.G., and Rieber, E.P. (2000). Generation of survivin-specific CD8 ${ }^{+} \mathrm{T}$ effector cells by dendritic cells pulsed with protein or selected peptides. Cancer Res. 60, 4845-4849.

Siegel, S., Wagner, A., Kabelitz, D., Marget, M., Coggin, J., Jr., Barsoum, A., Rohrer, J., Schmitz, N., and Zeis, M. (2003). Induction of cytotoxic T-cell responses against the oncofetal antigen-immature laminin receptor for the treatment of hematologic malignancies. Blood 102, 4416-4423.

Simons, J.W., Jaffee, E.M., Weber, C.E., Levitsky, H.I., Nelson, W.G., Carducci, M.A., Lazenby, A.J., Cohen, L.K., Finn, C.C., Clift, S.M., Hauda, K.M., Beck, L.A., Leiferman, K.M., Owens, A.H., Jr., Piantadosi, S., Dranoff, G., Mulligan, R.C., Pardoll, D.M., and Marshall, F.F. (1997). Bioactivity of autologous irradiated renal cell carcinoma vaccines generated by ex vivo granulocyte-macrophage colony-stimulating factor gene transfer. Cancer Res. 57, 1537-1546.

Sosman, J.A., Puzanov, I., and Atkins, M.B. (2007). Opportunities and obstacles to combination targeted therapy in renal cell cancer. Clin. Cancer Res. 13, 764s-769s.

Stevanovic, S. (2002). Identification of tumour-associated T-cell epitopes for vaccine development. Nat. Rev. Cancer 2, 514-520.

Therasse, P., Arbuck, S.G., Eisenhauer, E.A., Wanders, J., Kaplan, R.S., Rubinstein, L., Verweij, J., Van, G.M., van Oosterom, A.T., Christian, M.C., and Gwyther, S.G. (2000). New guidelines to evaluate the response to treatment in solid tumors. European Organization for Research and Treatment of Cancer, National Cancer Institute of the United States, National Cancer Institute of Canada. J. Natl. Cancer Inst. 92, 205-216.

van der Bruggen, P., Bastin, J., Gajewski, T., Coulie, P.G., Boel, P., De Smet C., Traversari, C., Townsend, A., and Boon, T.
(1994). A peptide encoded by human gene MAGE-3 and presented by HLA-A2 induces cytolytic T lymphocytes that recognize tumor cells expressing MAGE-3. Eur. J. Immunol. 24, 3038-3043.

Vonderheide, R.H., Hahn, W.C., Schultze, J.L., and Nadler, L.M. (1999). The telomerase catalytic subunit is a widely expressed tumor-associated antigen recognized by cytotoxic $\mathrm{T}$ lymphocytes. Immunity 10, 673-679.

Weinschenk, T., Gouttefangeas, C., Schirle, M., Obermayr, F., Walter, S., Schoor, O., Kurek, R., Loeser, W., Bichler, K.H., Wernet, D., Stevanovic, S., and Rammensee, H.G. (2002). Integrated functional genomics approach for the design of patient-individual antitumor vaccines. Cancer Res. 62, 58185827.

Yotnda, P., Firat, H., Garcia-Pons, F., Garcia, Z., Gourru, G., Vernant, J.P., Lemonnier, F.A., Leblond, V., and LangladeDemoyen, P. (1998). Cytotoxic T cell response against the chimeric p210 BCR-ABL protein in patients with chronic myelogenous leukemia. J. Clin. Invest. 101, 2290-2296.

Zhou, M., Peng, J.R., Zhang, H.G., Wang, H.X., Zhong, Z.H., Pan, X.Y., Chen, W.F., and Leng, X.S. (2005). Identification of two naturally presented MAGE antigenic peptides from a patient with hepatocellular carcinoma by mass spectrometry. Immunol. Lett. 99, 113-121.

Zhou, X., Jun, D.Y., Thomas, A.M., Huang, X., Huang, L.Q., Mautner, J., Mo, W., Robbins, P.F., Pardoll, D.M., and Jaffee, E.M. (2005). Diverse CD8 ${ }^{+}$T-cell responses to renal cell carcinoma antigens in patients treated with an autologous granulocyte-macrophage colony-stimulating factor genetransduced renal tumor cell vaccine. Cancer Res. 65, 10791088.

Address correspondence to: Prof. Dolores J. Schendel Helmholtz Zentrum München Institute of Molecular Immunology Marchioninistrasse 25 81377 Munich, Germany

E-mail: schendel@helmholtz-muenchen.de

Received for publication December 8, 2008; accepted after revision September 25, 2009.

Published online: January 26, 2010. 
